\title{
Experiences gathered and lessons learned from 20 years of RNA structure
}

\author{
JEFFREY S. KIEFT \\ Department of Biochemistry and Molecular Genetics and Howard Hughes Medical Institute, University of Colorado Denver School \\ of Medicine, Aurora, Colorado 80045, USA
}

I was honored to be asked to contribute to this issue. My own entry into the RNA world occurred close in time to the appearance of RNA (the journal, not the molecule), and I have been privileged to have had a front-row seat to several remarkable advances. While I don't classify myself as "only" an RNA structural biologist, RNA structure has defined much of my career. In what follows, I'll offer a few personal observations of how I've seen the RNA structure field grow and change and how these changes influenced my career. I'll also mention to interested students and post-docs that none of my career decisions involved any true planning or strategy. I was pretty clueless; I just did what was scientifically exciting to me. Maybe I was lucky, but I think if you do what you love, and pursue it passionately, you will be successful.

In the fall of 1993 I walked into Ignacio (Nacho) Tinoco's office at UC Berkeley for the first time, seeking a lab in which to study macromolecular structure. As far as I knew, except for a few exceptions like tRNA, RNA was the readily-degraded template for the synthesis of proteins and only proteins folded into interesting, complex and compact structures. But, the description of Nacho's research interests (in a printed booklet; there weren't webpages yet) mentioned three-dimensional structure of RNA. I was required to talk to at least three professors before I chose a lab, and since Nacho was studying structure, I figured I could spend a half hour thinking about RNA.

When I entered Nacho's office, I noticed two things: a secondary structure diagram of the Tetrahymena group I intron hanging on the wall and a box of Cheez-Its on his desk. Both were present in his office during my entire graduate career. To this day Cheez-Its still remind me of RNA structure. Nacho explained to me what the group I intron was, what it did, how we knew that many such RNAs had to fold up into a specific and compact structure, and that this fold was responsible for catalysis. What were the structural details? How did these RNAs pack into a compact structure? What were the principles of RNA folding and how did it relate to

\footnotetext{
Corresponding author: Jeffrey.Kieft@ucdenver.edu

Article and publication date are at http://www.rnajournal.org/cgi/doi/ 10.1261/rna.050831.115. Freely available online through the RNA Open Access option.
}

function? The answers to these questions were unknown, because unlike proteins, there were no high-resolution structures of such folded RNAs. After leaving Nacho's office, I couldn't stop thinking about the implications of what he had told me. It made sense that proteins could fold tightly, with their rich repertoire of 20 chemically diverse amino acids. But the fact that RNA, with only 4 nucleotides, could perform equally varied biological functions by adopting stable, complex three-dimensional structures...that seemed paradoxical, mysterious_almost magical! But it wasn't magic, it was thermodynamics and I knew I wanted to be part of solving this mystery. I had planned to think about RNA structure for about 30 minutes, but $20+$ years later it still occupies my mind. So, I thank Nacho for recruiting me to the world of RNA, and apologize for ever thinking proteins were as cool as RNA.

As a graduate student in Nacho's lab, my projects focused on using NMR to study RNA structure in the classic divideand-conquer approach used by many in the field at the time to study large RNAs. The idea was to divide up a larger RNA into smaller secondary structure elements, and then solve the structure of each in isolation. We knew the caveats to this approach, but we reasoned that by studying the isolated structures, then combining these structures with each other and with data from other approaches, we could gain insight into the structure of the larger RNA. Generating samples that gave good spectra required trying many RNAs that differed by small changes in their sequences. Many of the RNAs were conformationally dynamic on timescales that made their spectra uninterpretable for structure determination, or pushed the limits of what we could study (realistically, $<35$ nucleotides in length). Happily, isotopic labeling became a valid and powerful technique to help assign the spectra of larger RNAs. It was a time of coming up with clever ways to overcome these obstacles and pushing NMR analysis as far as possible. Many important RNA structures were solved by NMR during these years. The field learned key principles of RNA structure, discovered common motifs, and developed methods used to this day.

(C) $2015 \mathrm{Kieft}$ This article, published in RNA, is available under a Creative Commons License (Attribution-NonCommercial 4.0 International), as described at http://creativecommons.org/licenses/by-nc/4.0/. 
As I approached the last year of my time in Berkeley, I wanted to study bigger RNAs and see more complex folds than we could then access by NMR. Although NMR had promise to allow larger structures to be examined, the structure of minimal hammerhead ribozymes solved by X-ray crystallography (McKay and Klug labs) suggested to me that crystallography held equal promise. Then, in September of 1996, the crystal structure of the P4-P6 domain of a group I intron was reported by Jennifer Doudna's lab. I remember reading the paper while sitting in the waiting room of my dentist's office (the structure still reminds me of the dentist). While it was not the first crystal structure of an RNA, it was an important one for me: I was transfixed by the novel tertiary interactions and motifs, complex hydrogen bonding networks, bound metal ions in various coordination states, and regions of contorted backbone. This was what I imagined when I first looked at Nacho's secondary structure poster... what was two-dimensional had become three-dimensional. I knew I had to learn to crystallize RNA.

I started in Jennifer Doudna's lab at Yale in January, 1998. In her lab and many other pioneering labs, there was a lot of effort going into crystallizing various RNAs. I believe this period was important not only for the crystal structures it produced, but for developing the basic strategies and techniques that provide the foundation for RNA crystallization now. The questions were many: What RNAs should or could be crystallized? What features conferred "crystallizability" of an RNA and how could one assess this? How could one alter or engineer an RNA to enhance its crystallization properties? Should one screen condition space or RNA construct space? The techniques and strategies that were developed include (but are not limited to) the use of GAAA tetraloops to favor crystal constructs, Adrian Ferré-D’Amaré's (one of my bay-mates in Jennifer's lab) pioneering work of adding protein binding sites to RNAs and then co-crystallizing the RNA-protein complex, ways to design libraries of RNAs to screen for crystals, the utility of hexammine cations, etc. These techniques remain the foundation of RNA crystallography.

In addition to crystallography, there was a lot of biochemistry going on in the Doudna lab. In fact, my project there started by using biochemistry and biophysics to explore the function and structure of the hepatitis $\mathrm{C}$ virus (HCV) internal ribosome entry site (IRES). Nothing was known of this RNA's higher-order structure so I started with classic experiments: chemical and enzymatic probing, native gels, and mutagenesis. I quickly discovered that the HCV IRES RNA was different from the compactly folded RNAs I expected to study: It was extended, probably conformationally dynamic, and therefore a poor candidate for crystallography as a whole. This was not what I expected, and it forced me to rethink my experimental plan. But, I was able to learn a tremendous amount about this RNA from an overall architectural view and biochemically explore its interactions with the ribosome and initiation factors. This was very rewarding; to this day those experiments are among the ones I am most proud of. These studies were also important for motivating cryo-electron microscopy studies with Christian Spahn and Joachim Frank and for understanding how the IRES's structure drives function. I point this out because this experience taught me two important things: (1) Keep an open mind about the RNA structure you are studying; it may surprise you and lead you down a different path than you expected, and (2) a tremendous amount of structural information can be had without ever solving a structure. It is possible to use the data from methods like analytical ultracentrifugation, native gels, and small-angle X-ray scattering, as well as biochemical approaches like probing, mutagenesis with functional assays, etc. to develop rigorous predictions of an RNA's 3-D fold. In fact, in many cases one can learn so much by using these methods that when the structure is solved it is largely confirmatory. One can be a structural biologist without ever solving a structure if one is thinking structurally. I remain convinced that the best chance of solving the structure of an unexplored RNA comes from first thoroughly characterizing the biochemical and biophysical behavior of the RNA. Only then does one really know if, or how, to solve its structure, and how to interpret the structure once solved. That is one thing that has not changed in the last 20 years.

During my last years at Yale (2000-2001), I was unsure of my next career steps. I was asking myself: Should I go into academia or industry? If I wanted to start my own lab, did I have "the right stuff"? Did I still want to work on RNA structure? Then several more structures were solved that had a profound effect on my journey through the RNA world: the crystal structures of the $50 \mathrm{~S}$ and $30 \mathrm{~S}$ ribosomal subunits (labs of Peter Moore, Tom Stietz, Venki Ramakrishnan, and Ada Yonath). The complexity and beauty of the monolithic RNA cores of these subunits was astounding and it was exciting to literally look over the shoulders of colleagues as they built the $50 \mathrm{~S}$ subunit structure. This went straight to my RNAaddicted brain, re-igniting my curiosity about what RNA could do, reminding me how much more there was to learn, and proving to me that seemingly insurmountable problems could be solved with persistence and creativity. The solving of the ribosome crystal structure made it seem like almost anything was possible (including some department hiring me)!

In 2002, roughly nine years after entering the RNA world, I started my own lab. At the time, I sensed that the field of RNA structure was poised for major advances. The tools were in place and extremely talented researchers were in the field. I was not disappointed. A great example is found in the riboswitches, which were first discovered about the same time I was transitioning from post-doc to faculty. I remember sitting in my office and thinking: These are the perfect targets to employ all of the structural, biochemical, biophysical, and genetic tools now in place. Indeed, within a few years my good friend Rob Batey (another fellow post-doc in the Doudna Lab) would solve the first structure of a riboswitch in complex with its cognate ligand; others soon followed. It 
is amazing how quickly the field went from knowing little to having a robust structural and mechanistic framework for understanding these RNAs. This is not limited to the riboswitches; structures of novel small ribozymes, self-splicing introns, RNase P, etc. in various states continue to be reported at a rate that would not have seemed possible when the RNA journal started.

Now it is 2015. I don't know if there was, or is, or will be a Golden Age of RNA structure, but it is hard not to be excited about where we are now. Not only can we solve complex
RNA structures, but it is possible to combine RNA structures with detailed dynamics studies including those on the singlemolecule level. Cryo-EM promises to reveal the structures of novel large RNA-protein complexes captured in various states. Thus, we will increasingly be challenged to think about and explore RNA structures in larger biological contexts and link changes in structure to function. It is exciting stuff. I'm sure that the next 20 years will produce at least as many new discoveries as the last 20 years, and I hope that I will be a contributor. 

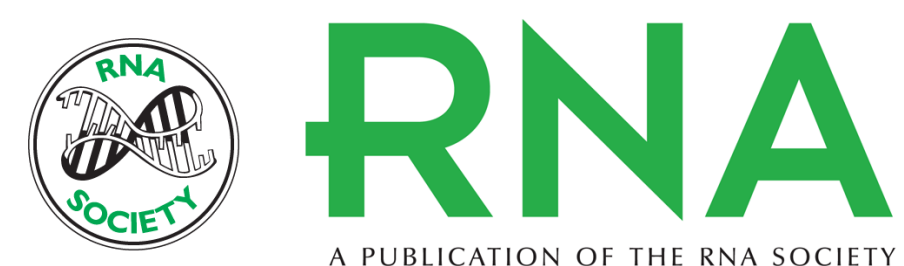

A PUBLICATION OF THE RNA SOCIETY

\section{Experiences gathered and lessons learned from 20 years of RNA structure}

Jeffrey S. Kieft

RNA 2015 21: 661-663

Open Access Freely available online through the RNA Open Access option.

Creative This article, published in $R N A$, is available under a Creative Commons License

Commons (Attribution-NonCommercial 4.0 International), as described at

License http://creativecommons.org/licenses/by-nc/4.0/.

Email Alerting Receive free email alerts when new articles cite this article - sign up in the box at the Service top right corner of the article or click here.

To subscribe to $R N A$ go to:

http://rnajournal.cshlp.org/subscriptions

(C) 2015 Kieft; Published by Cold Spring Harbor Laboratory Press for the RNA Society 